CORRECTION

https://doi.org/10.1038/s41586-018-0113-3

\title{
Author Correction: A Myc \\ enhancer cluster regulates normal \\ and leukaemic haematopoietic stem cell hierarchies
}

Carsten Bahr, Lisa von Paleske, Veli V. Uslu, Silvia Remeseiro, Naoya Takayama, Stanley W. Ng, Alex Murison, Katja Langenfeld, Massimo Petretich, Roberta Scognamiglio, Petra Zeisberger, Amelie S. Benk, Ido Amit, Peter W. Zandstra, Mathieu Lupien, John E. Dick, Andreas Trumpp \&

François Spitz

Correction to: Nature https://doi.org/10.1038/nature25193, published online 17 January 2018.

In the originally published version of this Letter, ref. 43 was erroneously provided twice. In the 'Estimation of relative cell-type-specific composition of AML samples' section in the Methods, the citation to ref. 43 after the GEO dataset GSE24759 is correct. However, in the 'Mice' section of the Methods, the citation to ref. 43 after 'TAMERE' should have been associated with a new reference ${ }^{1}$. The original Letter has been corrected online (with the new reference included as ref. 49).

1. Hérault, Y., Rassoulzadegan, M., Cuzin, F. \& Duboule, D. Engineering chromosomes in mice through targeted meiotic recombination (TAMERE). Nat. Genetics 20, 381-384 (1998). 